\section{Efficacy Verification of Team Learning Satisfaction, Problem Solving Ability, and Communication Ability of Problem Solving Process Classes Applying Action Learning, Problem-Based Learning, and Mentoring}

\author{
Hwang-Woo Byun \\ Department of Electrical Automation, Suncheon Jeil College, Suncheon, Korea
}

The purpose of this study was i) to design a teaching and learning model for problem solving ability class to which action learning (AL), problem-based learning (PBL), and Mentoring are applied, ii) implement the model to verify the effects of AL's on team learning, iii) analyze the enhancement of problem solving ability through PBL and iv) review development of communication skills through mentoring. The effect of team learning, improvement of problem solving ability within PBL, and improvement in communication through mentoring was verified through comparison of results from quantitative pre- and post-tests. Data was collected two times in the form of a questionnaire for 62 students at the beginning and at the end of the first semester of 2020. A paired samples t-test was among the methods of average comparison on the SPSS 18.0, used to determine differences in team learning satisfaction, problem solving ability, and communication skills based on experiences in AL, PBL, and Mentoring. The results of the test verified the efficacy of PSP class to which AL, PBL, and Mentoring were applied.

Keywords: Action Learning; Problem-Based Learning; Mentoring; Problem Solving Process

\section{INTRODUCTION}

The World Economic Forum (WEF) in 2017 publicized ten skills required to thrive in the Fourth Industrial Revolution: (1) Complex Problem Solving, (2) Critical Thinking, (3) Creativity, (4) People Management, (5) Coordinating with Others, (6) Emotional Intelligence, (7) Judgment and Decision Making, (8) Service Orientation, (9) Negotiation, and (10) Cognitive Flexibility. A competent, talented person for the 21st century can be one who not only possesses a wide range of knowledge but also accepts new knowledge, applies it to problem solving, and carries out roles and functions as a member of society. Given the WEF's list of skills, vocational colleges in the provinces in Korea, in particular, should develop a variety of teaching methods; consideration needs to be given to the significance of nurturing talent, as well as seeking improvement in adaptability, problem-solving ability, communication skills, and interpersonal ability. In these abilities there is a perceived deterioration in student levels of ability.

This researcher has been conducting problem solving process (PSP) classes since 2016 in line with the trend of the times and the goal of cultivating talent in college students. The PSP class consists of AL, PBL, and Mentoring. Here, AL is a method where learning occurs

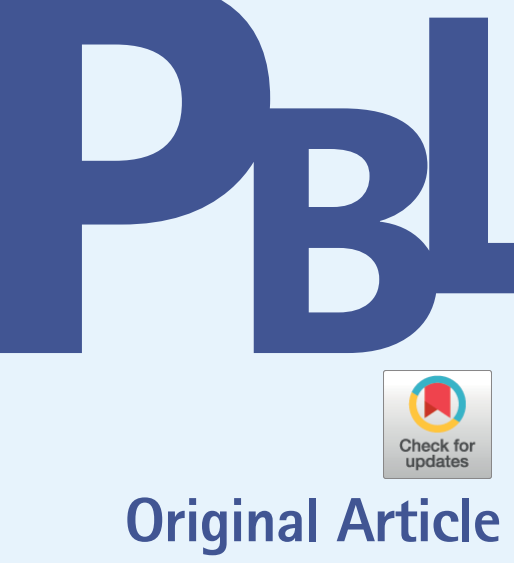

pISSN 2288-8675 · elSSN 2508-9145

J Probl Based Learn 2020;7(2):63-73

https://doi.org/10.24313/jpbl.2020.00269

Received: July 12, 2020

Revised: September 27, 2020

Accepted: September 30, 2020

Corresponding author:

Hwang-Woo Byun,

Department of Electrical Automation, Suncheon Jeil College, 17, Jeildaehakgil, Suncheon, 57997, Korea

Tel: +82-61-740-1354

Fax: +82-61-740-1466

Email: byunhwoo@suncheon.ac.kr
(C) Copyright 2020 International Society for Problem-Based Learning

(c) This is an Open Access article distributed under the terms of the Creative Commons Attribution Non-Commercial License (http://creativecommons.org/licenses/ by-nc/4.0/) which permits unrestricted non-commercial use, distribution, and reproduction in any medium, provided the original work is properly cited. 
through a process to derive a solution to a task. PBL is a method in which learners jointly discuss problem-solving methods and then prepare a common solution through both individual and cooperative learning processes. Mentoring is a way to improve a mentee's skills and potential with the guidance and advice of a mentor.

The purpose of this study was i) to design a teaching and learning model for PSP class to which action learning (AL), problem-based learning (PBL), and Mentoring are applied, ii) implement the model to verify the effects of AL's on team learning, iii) analyze the enhancement of problem solving ability through PBL and iv) review development of communication skills through Mentoring. Quantitative tests were applied with the aim of presenting directions for teaching and learning that can effectively respond to the college's quest to contribute to a knowledge-based society.

The research hypotheses used in this study were as follows:

1) Verification of the significance of responses to the question: "Does AL change learners' satisfaction with team learning?" $\mathrm{AL}$ is a method of education and training in which teams are formed to solve problems. Therefore, this paper mainly studies the effect on learning among team members through collaboration.

Hypothesis: AL education is effective in increasing learners' satisfaction with team learning.

2) Verification of the significance of responses to the question: "Does PBL change learners' problem solving ability?" Hypothesis: PBL education is effective in increasing learner's problem solving ability.

3) Verification of the significance of responses to the question: "Does Mentoring change learners' communication skills?" Mentoring involves mentors who give advice and mentees who receive advice. Therefore, in this paper, the effect of communication between mentor and mentee is central to perceived outcomes.

Hypothesis: Mentoring education is effective in improving learners' communication skills.

4) Verification of the significance of responses to the question: "Does Mentoring improve mentors' satisfaction with their college life?”

\section{LITERATURE REVIEW}

Theoretical Review: This section examines a selection of concepts within previous studies on the effects of team learning satisfaction, problem solving ability improvement, and communication skills, the variables within the PSP classroom approach.

\section{1) Team learning}

Team-based learning (TBL), first introduced by Larry Michaelsen, a professor at Oklahoma University in the 1970s, is a special teaching strategy in which simple small groups are converted into teams for optimal performance (Michaelsen, 2009). The TBL instructors are designers and managers of overall curriculum, serving as a manager of knowledge (Shin, 2019). TBL can have positive effects on learner's motivation, learning attitude, participation, communication skills, academic achievement, self-directed learning, academic self-efficacy, emotional intelligence, and satisfaction (Kim Yun Kyung, Kim Nuri, 2015; Lee Kyung Hee, Son Eun Kyung, 2012; Ha Chae Yeon, Lee Soo Young, 2014). According to these studies, TBL affects attitudes to learning and satisfaction of learners on a relatively consistent basis. This study aims to examine team participation, reliability between team members, team learning satisfaction, and team learning effectiveness through TBL.

\section{2) Problem solving ability}

Problem solving ability is an intellectual and creative process of quickly and effectively resolving differences between the current state and the target to be achieved by a problem solver (Kahney, 1986). Solving a problem requires a goal achievement, a process of change in thinking and behavior to achieve the goal (Lee et al., 2003;Park, 2017). In the mid to late 1900s researchers of cognitive theory regarded problem solving ability and creativity as the same cognitive phenomenon (Guilford, 1967) or viewed creativity as a form of problem solving (Mumford, et al., 1991). Originality, flexibility, and fluency of creativity are generally regarded to be inseparable from problem solving ability; the two concepts of problem solving ability and creativity were combined into one complex concept, called Creative Problem Solving (CPS) (Feldhusen \& Treffinger, 1985). To analyze problem solving ability, this study examined orientation of problems, analysis of problem causes, deduction and verification of solutions, practicability of solutions, and verification and evaluation of practice.

\section{3) Communication skills}

A mentor and mentee are involved in mentoring; communication skills between the two is very important. Carkhuff (1972) cited empathy, respect, warm expressions, specificity of expression, genuineness, self-disclosure, confrontation, and immediacy as factors communication skills (as cited in Ryu, 2014). According toLee et al., (2003), the components of communication skills include (1) interpreting dialogue from collecting information about and listening to them, (2) playing a role by overcoming stereotypical thinking and communicating creatively and with 
open-mindedness, (3) expressing their own thoughts without pretension, (4) setting goals to lead communication in which one presents one's own opinions clearly, and (5) converting messages to understand the words and stance of the other person (Shin, 2014). This study examined listening, sincerity, the positive nature of expression, consideration and understanding, and satisfaction with college life, in order to analyze the appropriateness of communication skills.

Communication of Teaching Methods: Previous studies on $\mathrm{AL}, \mathrm{PBL}$, and Mentoring, highlighted the relationships among components of teaching and learning models of PSL class.

1) AL - consists of six components: a task to be solved, a constituent learning team, a reflection on learning effects and a set of questions mutually agreed upon by learners, a willingness to practice, an approach to learning through task solving, and involvement of a learning coach (Marquardt, 1999). To experience successful learning in $\mathrm{AL}$, all criteria should be satisfied (Kim \& Um, 2014, 2011).

Table 1, shows how participation in the six components of action-oriented learning has the potential to lead to solutions to problems posed by a team (or organization), in this case, through the action learning process proposed by Lee (2018).

2) PBL has been the focus of scholars for decades. PBL is, according to Barrows \& Tamblyn (1980), i) learning from processes and activities for understanding or solving prob-

Table 1. AL processes presented in previous studies

\begin{tabular}{ll}
\hline Division & O'Neil \& Marsick (2007/2014) \\
\hline Clarification and cause analysis of tasks & 1. Checking tasks \\
& 2. Drawing and verifying hypotheses \\
& 3. Drawing necessary items \\
& 4. Collecting data and benchmarking \\
Drawing solutions for tasks & 5. Developing ideas for solution \\
Practicing task solutions & 6. Decision making \\
Reflection and evaluation & 7. Authorization and participation \\
& 8. Practicing \\
& 9. Evaluating performance \\
\end{tabular}

lems, or ii) a method of learning or teaching in which problematic situations are used for students to actively participate in learning processes. Albanese \& Mitchell (1993) defined $\mathrm{PBL}$ as a teaching method in which problems are used to teach students problem solving ability and basic knowledge. Gallagher \& Stepien (1996) reported that PBL is a cyclical process of defining a problem, selecting hypotheses for learning, and detecting concrete learning problems. Cho Yeon Sun (2006) defined PBL as an educational approach in which learners are led to learn the necessary knowledge by themselves through processes of problem solving from real-world, non-structured problems (Kim, 2010).

3) Mentoring - Park Sung Mi (2006), using psycho-social, career-development, role-modeling, friendship protection as a criterion-related mentoring function scale, reported development and validation of tools to measure Mentoring functions for college students. Kim Ji Eung (2008) dealt with the effects of college students' Mentoring functions on adaptation to and satisfaction with college life (Kim, 2010).

\section{METHODS}

This paper has received IRB approval from Suncheon Jeil College Industry-Academy Cooperation Foundation (IACF) (Approval number: IACF-2020-1).

Table 2 shows the group of study subjects divided into mentors and mentees.

Figure 1 shows the conceptual model used in the study; $\mathrm{N}=62$ subjects - mentors and mentees

Figure 2 shows the approach to this study and the flow of the teaching and learning method. This study began at the end of 2019 and consists of the steps of development of an APM teaching and learning model, modification and supplementation of the model, model application, results analysis.

In this study, 65 freshmen majoring in electrical engineering at Suncheon Jeil College who took the PSP class were divided into three groups A, B and C according to their Student Number. Three were excluded due to military enlistment; 62 students

Table 2. Subject groups and mentors and mentees (Unit: Persons, \%)

\begin{tabular}{|c|c|c|c|c|c|c|c|c|}
\hline \multirow{2}{*}{ Groups } & \multicolumn{6}{|c|}{ Freshmen } & \multirow{2}{*}{\multicolumn{2}{|c|}{ Total }} \\
\hline & \multicolumn{2}{|c|}{ A } & \multicolumn{2}{|c|}{ B } & \multicolumn{2}{|c|}{ C } & & \\
\hline \multirow[t]{2}{*}{ Experimental groups } & \multicolumn{2}{|c|}{21} & \multicolumn{2}{|c|}{21} & \multicolumn{2}{|c|}{20} & \multicolumn{2}{|c|}{62 (persons) } \\
\hline & \multicolumn{2}{|c|}{33.9} & \multicolumn{2}{|c|}{33.9} & \multicolumn{2}{|c|}{32.2} & \multicolumn{2}{|c|}{$100(\%)$} \\
\hline \multirow[t]{3}{*}{ Subject groups } & Mentors & Mentees & Mentors & Mentees & Mentors & Mentees & Mentors & Mentees \\
\hline & 4 & 17 & 4 & 17 & 4 & 16 & 12 (persons) & 50 (persons) \\
\hline & 19.1 & 80.9 & 19.1 & 80.9 & 20 & 80 & $19.4(\%)$ & $80.6(\%)$ \\
\hline
\end{tabular}




\begin{tabular}{|c|c|c|c|c|}
\hline Subjects & $\begin{array}{l}\text { Teaching } \\
\text { Methods }\end{array}$ & \multirow{4}{*}{$\Rightarrow$} & $\begin{array}{l}\text { Independent } \\
\text { Variables }\end{array}$ & $\begin{array}{l}\text { Dependent } \\
\text { Variables }\end{array}$ \\
\hline Mentor/mentee & $\mathrm{AL}$ & & Team learning & $\begin{array}{l}\text { Satisfaction with } \\
\text { team learning }\end{array}$ \\
\hline \multirow{2}{*}{$\begin{array}{l}\text { Experimental } \\
\text { groups: A, B } \\
\text { and C (Freshmen) }\end{array}$} & PBL & & $\begin{array}{l}\text { Problem-based } \\
\text { learning }\end{array}$ & $\begin{array}{l}\text { Problem-solving } \\
\text { ability }\end{array}$ \\
\hline & Mentoring & & $\begin{array}{l}\text { Mentoring } \\
\text { learning }\end{array}$ & $\begin{array}{l}\text { Communication } \\
\text { skills between } \\
\text { mentors and } \\
\text { mentees }\end{array}$ \\
\hline
\end{tabular}

Figure 1. Conceptual model of study.

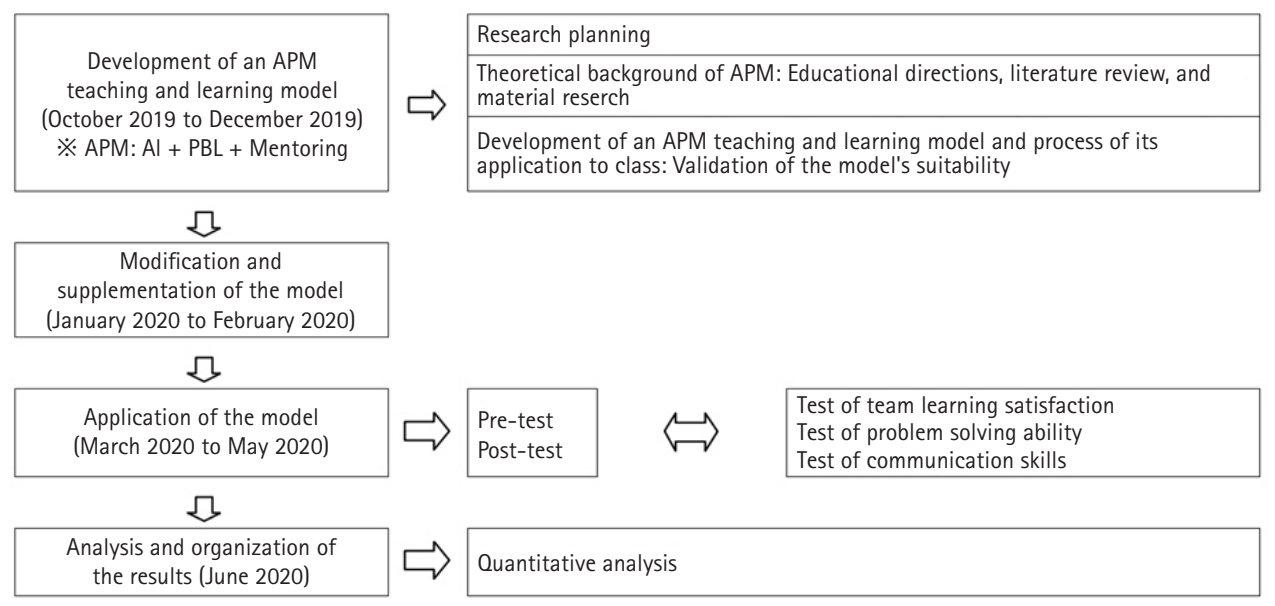

Figure 2. Research model and flow of teaching and learning.

were surveyed. Of the 62 students taking PSP classes, 1 female and 61 males - 12 were Mentors (19.4\%) and 50 Mentees (80.6\%).

The following test tools were used to determine team learning satisfaction, problem solving ability, and the nature of communication skills.

\section{1) Team learning satisfaction}

This study modified and supplemented the tool for learning satisfaction revised by Kim Yeon Soon (2013) to measure learner's satisfaction with team learning. The sub-elements included the following items - two for team participation, two for reliability among team members, three for team learning satisfaction, and five for team learning effectiveness. For responses to 12 questions, a five-point Likert scale was used - 1 indicating negative to 5 positive.

\section{2) Problem solving ability}

To measure the problem solving ability of learners, the tool used, focused on college students and adults, one of the life-competencies measurement tools developed by the Korean Educational Development Institute (KEDI) (Lee et al., 2003). The sub-elements included three items for orientation of problems, two for analysis of problem causes, three for deduction and verification of solutions, two for practicability of solutions, and two for verification and evaluation of practice. A five-point Likert scale was applied to 12 questions, from 1 point as negative to 5 points - positive.

\section{3) Communication skills}

This researcher reorganized the tool for measuring communication skills of college students and adults, one of the life-competencies measurement tools developed by the KEDI (Lee et al., 2003). The sub-elements included four items for listening, two for sincerity, three for positivity of expression, and three for consideration and understanding. Responses to 12 questions were based on a five-point Likert scale ( 1 indicating negative and 5 positive).

\section{DESIGN AND PROCEDURES}

\section{1) Experimental design}

A quantitative explanatory design involved comparison between pre- and post surveys of perceptions of 62 freshmen who 
took the PSP class; 12 mentors and 50 mentees participated. A control group was not used. The first survey immediately after forming teams with mentors at Week 1 and the second in Week 14 at the end of the course. The questionnaire consisted of 12 questions for team learning satisfaction, 12 for problem solving ability, and 12 for communication skills.

\section{2) Experimental procedures}

Figure 3 illustrates the experimental process from mentor selection to school termination. Completion of service was the criterion for mentor selection of 12 students. Mentors with military service were deemed credible among their classmates, had a strong spirit of service, could establish smooth relationships and were interested in mentoring their peers. The mentor's main role was to listen to mentee's concerns and provide psychological support and academic support.

\section{3) PSP class content}

Table 3 shows PSP lectures conducted weekly, attended by both mentors and mentees. Hourly classes were held for 15 weeks.

\section{ANALYSIS}

The first of 2 surveys included all the original 65 subjects; Week 14 involved 62 as 3 took leave due to military service enlistment. Their surveys were excluded from the data. Comparisons across the identical surveys showed perceptions of the effects of AL, PBL, and Mentoring on the learning experience. SPSS 18.0 was used to input and analyze the data. A paired sample t-test among was used to determine differences in perceptions about team learning satisfaction, problem solving ability, and communication skills, based on experiences in AL, PBL, and Mentoring.

\section{RESULTS}

Pre-and post-surveys provided insight into student perceptions of their experiences with a PSP class to which AL, PBL, and Mentoring were applied. Comparison between the baseline and summative data verified the effects of team learning within $\mathrm{AL}$ and improvements in problem solving ability and communication skills.

\begin{tabular}{|l|l|l|l|}
\hline $\begin{array}{l}\text { Selecting } \\
\text { mentors }\end{array}$ \\
\hline $\begin{array}{l}12 \text { students } \\
\text { selected }\end{array}$
\end{tabular}

Figure 3. Flow of problem solving process class.

Table 3. Problem solving process class content per week

\begin{tabular}{|c|c|c|c|}
\hline & Schedule & Topic & Main Content \\
\hline \multirow[t]{14}{*}{ APM } & The 1st to 3rd week & Understanding of $\mathrm{AL}, \mathrm{PBL}$, and Mentoring & - Personal communication skills \\
\hline & & & - Team communication skills (how to improve team dynamics) \\
\hline & & & - How to run a team meeting \\
\hline & The 4th to 6th week & PBL-type task execution & - How to select tasks \\
\hline & & & - Understanding models of task performance \\
\hline & & & - Learning task definition steps \\
\hline & The 7 th to 11 th week & & - Learning task research steps \\
\hline & & & - Learning steps of deduction and validation of solutions \\
\hline & & & - Learning steps of preparing action plans \\
\hline & The 12 th to $13 \mathrm{rd}$ week & PBL comprehensive practice & - Practicing step-by-step team roles (actual activities by teams) \\
\hline & & & - Mutual feedback \\
\hline & The 14th to 15 th week & PBL follow-up & - Sharing experiences of practice \\
\hline & & & - Identifying difficulties and mutual feedback \\
\hline & & & - Skill-up for improving team learning competency \\
\hline
\end{tabular}




\section{1) Effects of AL on team learning satisfaction}

To analyze statistical differences in team learning satisfaction based on AL experiences, paired sample t-tests were applied, with two items for team participation, two for reliability between team members, three for team learning satisfaction, and five for team learning effectiveness on the Likert 5-point scale. In this study, "AL education" was selected as an independent variable, and team participation, reliability between team members, team learning satisfaction, and team learning effectiveness at the beginning and the end of the semester were selected as verification variables for analysis. To interpret and determine the results, a null hypothesis "AL education is not effective on increasing learners' satisfaction with team learning" and a research hypothesis "AL education is effective on increasing learners' satisfaction with team learning" were used.

The analysis methods used in Table 4 and 5, Table 6 and 7, Table 8 and 9 show paired t-tests. This analytical method measuring one sample twice (pre-post measurement), determines any difference between the two measurements. Table 4, Table 6, and Table 8 are 'paired sample statistics and analyze the difference in satisfaction between results at the beginning and the end of the semester. Table 5, Table 7, and Table 9 are 'paired sample tests' to determine whether the study hypothesis is rejected given the significance level.

Table 4 shows the results of analyses at the beginning and the end of the semester for evaluating team learning satisfaction based on AL experiences. The number of samples $(\mathrm{N})$ is 62 , and average means the average satisfaction based on AL experiences. In all the verification variables, the averages remarkably increased at the end of the semester in comparison to the beginning; for 'Team participation', the average increased from 1.66 (low satisfaction) at the beginning to 4.21 (high) at the end.

Table 5 shows the results of analyzing test differences in the paired samples used at the beginning and end of the semester to evaluate team learning satisfaction based on AL experiences. When the significance levels were analyzed, the absolute value of the t-value was from 22.774 ( $\min$.) up to 36.421 (max.), which exceeded 1.96 , for all the verification variables. The significance

Table 4. Differences in statistics of team learning satisfaction based on action learning experiences

\begin{tabular}{|c|c|c|c|c|c|c|c|c|}
\hline \multicolumn{6}{|c|}{ Statistics of paired samples } & \multicolumn{3}{|c|}{ Correlation coefficients of paired samples } \\
\hline & & Average & $\mathrm{N}$ & $\begin{array}{l}\text { Standard } \\
\text { deviation }\end{array}$ & $\begin{array}{l}\text { Standard error } \\
\text { of average }\end{array}$ & & $\begin{array}{l}\text { Correlation } \\
\text { coefficients }\end{array}$ & $\begin{array}{l}\text { Significance } \\
\text { probability }\end{array}$ \\
\hline \multirow[t]{2}{*}{ Team participation } & Beginning of semester & 1.66 & 62 & 0.651 & 0.083 & Beginning \& end of semester & 0.215 & 0.093 \\
\hline & End of semester & 4.21 & 62 & 0.750 & 0.095 & & & \\
\hline \multirow{2}{*}{$\begin{array}{l}\text { Reliability between } \\
\text { team members }\end{array}$} & Beginning of semester & 1.35 & 62 & 0.630 & 0.080 & Beginning \& end of semester & 0.094 & 0.466 \\
\hline & End of semester & 4.66 & 62 & 0.676 & 0.086 & & & \\
\hline \multirow{2}{*}{$\begin{array}{l}\text { Team learning } \\
\text { satisfaction }\end{array}$} & Beginning of semester & 1.71 & 62 & 0.555 & 0.070 & Beginning \& end of semester & -0.038 & 0.772 \\
\hline & End of semester & 4.35 & 62 & 0.482 & 0.061 & & & \\
\hline \multirow{2}{*}{$\begin{array}{l}\text { Team learning } \\
\text { effectiveness }\end{array}$} & Beginning of semester & 1.39 & 62 & 0.523 & 0.066 & Beginning \& end of semester & -0.037 & 0.776 \\
\hline & End of semester & 4.77 & 62 & 0.493 & 0.063 & & & \\
\hline
\end{tabular}

Table 5. Test differences in paired samples of team learning satisfaction based on action learning experiences

\begin{tabular}{|c|c|c|c|c|c|c|c|c|c|}
\hline \multicolumn{10}{|c|}{ Test of paired samples } \\
\hline & & \multicolumn{5}{|c|}{ Paired differences } & \multirow{3}{*}{$\mathrm{t}$} & \multirow{3}{*}{$\begin{array}{l}\text { Degree of } \\
\text { freedom }\end{array}$} & \multirow{3}{*}{$\begin{array}{l}\text { Significance } \\
\text { probability } \\
\text { (both) }\end{array}$} \\
\hline & & \multirow{2}{*}{ Average } & \multirow{2}{*}{$\begin{array}{l}\text { Standard } \\
\text { deviation }\end{array}$} & \multirow{2}{*}{$\begin{array}{l}\text { Standard error } \\
\text { of average }\end{array}$} & \multicolumn{2}{|c|}{$\begin{array}{l}\text { 95\% confidence interval of } \\
\text { difference }\end{array}$} & & & \\
\hline & & & & & Lowest & Highest & & & \\
\hline Team participation & $\begin{array}{l}\text { Beginning to end of } \\
\text { semester }\end{array}$ & -2.548 & 0.881 & 0.112 & -2.772 & -2.325 & -22.774 & 61 & .000 \\
\hline $\begin{array}{l}\text { Reliability between } \\
\text { team members }\end{array}$ & $\begin{array}{l}\text { Beginning to end of } \\
\text { semester }\end{array}$ & -3.306 & 0.879 & 0.112 & -3.53 & -3.083 & -29.604 & 61 & .000 \\
\hline $\begin{array}{l}\text { Team learning } \\
\text { satisfaction }\end{array}$ & $\begin{array}{l}\text { Beginning to end of } \\
\text { semester }\end{array}$ & -2.645 & 0.749 & 0.095 & -2.835 & -2.455 & -27.819 & 61 & .000 \\
\hline $\begin{array}{l}\text { Team learning } \\
\text { effectiveness }\end{array}$ & $\begin{array}{l}\text { Beginning to end of } \\
\text { semester }\end{array}$ & -3.387 & 0.732 & 0.093 & -3.573 & -3.201 & -36.421 & 61 & .000 \\
\hline
\end{tabular}


probability (for both) was 0.000 . Thus, it is reasonable to consider that the research hypothesis is supported. The significance probability is between 0 and 1 , and if the significance level is less than 0.05 , the research hypothesis is adopted with a probability of $95 \%$.

\section{2) Effects of PBL on problem solving ability}

To analyze statistical differences in problem solving ability

Table 6. Differences in statistics of problem solving ability based on problem-based learning experiences

\begin{tabular}{|c|c|c|c|c|c|c|c|c|}
\hline \multicolumn{6}{|c|}{ Statistics of paired samples } & \multicolumn{3}{|c|}{ Correlation coefficients of paired samples } \\
\hline & & Average & $\mathrm{N}$ & $\begin{array}{l}\text { Standard } \\
\text { deviation }\end{array}$ & $\begin{array}{l}\text { Standard error } \\
\text { of average }\end{array}$ & & $\begin{array}{l}\text { Correlation } \\
\text { coefficients }\end{array}$ & $\begin{array}{l}\text { Significance } \\
\text { probability }\end{array}$ \\
\hline \multirow[t]{2}{*}{ Orientation of problems } & Beginning of semester & 1.66 & 62 & 0.626 & 0.079 & Beginning \& end of semester & 0.023 & 0.859 \\
\hline & End of semester & 4.69 & 62 & 0.642 & 0.082 & & & \\
\hline \multirow{2}{*}{$\begin{array}{l}\text { Analysis of problems' } \\
\text { causes }\end{array}$} & Beginning of semester & 1.48 & 62 & 0.62 & 0.079 & Beginning \& end of semester & -0.090 & 0.486 \\
\hline & End of semester & 4.35 & 62 & 0.482 & 0.061 & & & \\
\hline \multirow{2}{*}{$\begin{array}{l}\text { Deduction and } \\
\text { verification of solutions }\end{array}$} & Beginning of semester & 1.82 & 62 & 0.529 & 0.067 & Beginning \& end of semester & -0.093 & 0.471 \\
\hline & End of semester & 4.77 & 62 & 0.493 & 0.063 & & & \\
\hline \multirow[t]{2}{*}{ Practicability of solutions } & Beginning of semester & 1.6 & 62 & 0.664 & 0.084 & Beginning \& end of semester & -0.001 & 0.991 \\
\hline & End of semester & 4.92 & 62 & 0.275 & 0.035 & & & \\
\hline \multirow{2}{*}{$\begin{array}{l}\text { Verification and } \\
\text { evaluation of practice }\end{array}$} & Beginning of semester & 1.53 & 62 & 0.646 & 0.082 & Beginning \& end of semester & 0.059 & 0.648 \\
\hline & End of semester & 4.73 & 62 & 0.45 & 0.057 & & & \\
\hline
\end{tabular}

Table 7. Differences in paired-samples test of problem solving ability based on problem-based learning experiences

\begin{tabular}{|c|c|c|c|c|c|c|c|c|c|}
\hline \multicolumn{10}{|c|}{ Test of paired samples } \\
\hline & & \multicolumn{5}{|c|}{ Paired differences } & \multirow{3}{*}{$\mathrm{t}$} & \multirow{3}{*}{$\begin{array}{l}\text { Degree of } \\
\text { freedom }\end{array}$} & \multirow{3}{*}{$\begin{array}{l}\text { Significance } \\
\text { probability } \\
\text { (both) }\end{array}$} \\
\hline & & \multirow{2}{*}{ Average } & \multirow{2}{*}{$\begin{array}{l}\text { Standard } \\
\text { deviation }\end{array}$} & \multirow{2}{*}{$\begin{array}{l}\text { Standard error } \\
\text { of average }\end{array}$} & \multicolumn{2}{|c|}{$\begin{array}{l}\text { 95\% confidence } \\
\text { interval of difference }\end{array}$} & & & \\
\hline & & & & & Lowest & Highest & & & \\
\hline Orientation of problems & Beginning to end of semester & -3.032 & 0.886 & 0.113 & -3.257 & -2.807 & -26.934 & 61 & .000 \\
\hline $\begin{array}{l}\text { Analysis of problems' } \\
\text { causes }\end{array}$ & Beginning to end of semester & -2.871 & 0.82 & 0.104 & -3.079 & -2.663 & -27.585 & 61 & .000 \\
\hline $\begin{array}{l}\text { Deduction and verification } \\
\text { of solutions }\end{array}$ & Beginning to end of semester & -2.952 & 0.756 & 0.096 & -3.144 & -2.760 & -30.746 & 61 & .000 \\
\hline Practicability of solutions & Beginning to end of semester & -3.323 & 0.719 & 0.091 & -3.505 & -3.140 & -36.379 & 61 & .000 \\
\hline $\begin{array}{l}\text { Verification and evaluation } \\
\text { of practice }\end{array}$ & Beginning to end of semester & -3.194 & 0.765 & 0.097 & -3.388 & -2.999 & -32.880 & 61 & .000 \\
\hline
\end{tabular}

Table 8. Differences in statistics of communication skills based on Mentoring experiences

\begin{tabular}{|c|c|c|c|c|c|c|c|c|}
\hline \multicolumn{6}{|c|}{ Statistics of paired samples } & & \multirow[b]{2}{*}{$\begin{array}{l}\text { Correlation } \\
\text { coefficients }\end{array}$} & \multirow[b]{2}{*}{$\begin{array}{l}\text { Significance } \\
\text { probability }\end{array}$} \\
\hline & & Average & $\mathrm{N}$ & $\begin{array}{l}\text { Standard } \\
\text { deviation }\end{array}$ & $\begin{array}{l}\text { Standard error } \\
\text { of average }\end{array}$ & & & \\
\hline \multirow[t]{2}{*}{ Listening } & Beginning of semester & 1.68 & 62 & 0.647 & 0.082 & Beginning \& end of semester & 0.077 & 0.550 \\
\hline & End of semester & 4.16 & 62 & 0.729 & 0.093 & & & \\
\hline \multirow[t]{2}{*}{ Sincerity } & Beginning of semester & 1.5 & 62 & 0.647 & 0.082 & Beginning \& end of semester & -0.037 & 0.774 \\
\hline & End of semester & 4.65 & 62 & 0.680 & 0.086 & & & \\
\hline \multirow{2}{*}{$\begin{array}{l}\text { Positiveness of } \\
\text { expression }\end{array}$} & Beginning of semester & 2.23 & 62 & 2.614 & 0.332 & Beginning \& end of semester & -0.078 & 0.549 \\
\hline & End of semester & 4.35 & 62 & 0.482 & 0.061 & & & \\
\hline \multirow{2}{*}{$\begin{array}{l}\text { Consideration } \\
\text { and understanding }\end{array}$} & Beginning of semester & 1.6 & 62 & 0.664 & 0.084 & Beginning \& end of semester & -0.182 & 0.156 \\
\hline & End of semester & 4.77 & 62 & 0.493 & 0.063 & & & \\
\hline
\end{tabular}


Table 9. Differences in paired samples test of communication skills based on Mentoring experiences

\begin{tabular}{|c|c|c|c|c|c|c|c|c|c|}
\hline \multicolumn{10}{|c|}{ Test of paired samples } \\
\hline & & \multicolumn{5}{|c|}{ Paired differences } & \multirow{3}{*}{$t$} & \multirow{3}{*}{$\begin{array}{l}\text { Degree of } \\
\text { freedom }\end{array}$} & \multirow{3}{*}{$\begin{array}{l}\text { Significance } \\
\text { probability } \\
\text { (both) }\end{array}$} \\
\hline & & \multirow{2}{*}{ Average } & \multirow{2}{*}{$\begin{array}{l}\text { Standard } \\
\text { deviation }\end{array}$} & \multirow{2}{*}{$\begin{array}{l}\text { Standard error } \\
\text { of average }\end{array}$} & \multicolumn{2}{|c|}{$\begin{array}{l}\text { 95\% confidence } \\
\text { interval of difference }\end{array}$} & & & \\
\hline & & & & & Lowest & Lowest & & & \\
\hline Listening & Beginning to end of semester & -2.484 & 0.936 & 0.119 & -2.722 & -2.246 & -20.887 & 61 & .000 \\
\hline Sincerity & Beginning to end of semester & -3.145 & 0.956 & 0.121 & -3.388 & -2.903 & -25.918 & 61 & .000 \\
\hline Positiveness of expression & Beginning to end of semester & -2.129 & 2.695 & 0.342 & -2.813 & -1.445 & -6.221 & 61 & .000 \\
\hline $\begin{array}{c}\text { Consideration and } \\
\text { understanding }\end{array}$ & Beginning to end of semester & -3.177 & 0.897 & 0.114 & -3.405 & -2.950 & -27.901 & 61 & .000 \\
\hline
\end{tabular}

based on PBL experiences, this study conducted a paired sample t-test before and after the educational event, with three items for orientation of problems, two for analysis of problems' causes, three for deduction and verification of solutions, two for practicability of solutions, and two items for verification and evaluation of practice.

In this study, "PBL education" was selected as an independent variable, and orientation of problems, analysis of problems' causes, deduction and verification of solutions, practicability of solutions, and verification and evaluation of practice at the beginning and the end of the semester were selected as verification variables for analysis. To interpret and determine the results, a null hypothesis "PBL education is not effective on increasing learner's problem-solving ability" and a research hypothesis "PBL education is effective on increasing learner's problem-solving ability” were used. According to the definition of Gallagher \& Stepien (1996), PBL is a cyclical process of defining a problem in a problem situation, setting hypotheses necessary for learning, and finding specific learning problems. Therefore, we needed to verify student problem solving ability after learning with PBL methods.

Table 6 shows the results of analysis at the beginning and end of semester to evaluate satisfaction with problem solving ability based on PBL experiences. Average means the average satisfaction based on PBL experiences. In all the verification variables, the averages remarkably increased at the end of the semester in comparison to the beginning; for orientation of problems, the average increased from 1.66 at the beginning to 4.69 at the end.

Table 7 shows the results of analyzing test differences in paired samples used at the beginning and the end of the semester to evaluate problem solving ability based on PBL experiences. When the significance levels were analyzed, the absolute value of the t-value was from 26.934 ( $\mathrm{min}$.) up to 36.379 (max.), which exceeded 1.96, for all the verification variables. The significance probability (for both) was 0.000 . Thus, it is reasonable to consider that the research hypothesis is supported.

\section{3) Effects of Mentoring on communication skills}

To analyze statistical differences in communication skills based on Mentoring experiences, a paired sample t-test before and after the educational initiative was undertaken, with four items for listening, two for sincerity, three for positivity in expression, and three for consideration and understanding.

"Mentoring" was selected as an independent variable, and listening, sincerity, positivity of expression, and consideration and understanding at the beginning and end of semester were selected as verification variables for analysis. To interpret and determine the results, a null hypothesis "Mentoring education is not effective on improving learners' communication skills" and a research hypothesis "Mentoring education is effective on improving learners' communication skills" were used.

Table 8 shows the results of correspondence analysis at the beginning and end of semester for evaluating satisfaction with communication skills based on Mentoring experiences. Average means the average satisfaction based on Mentoring experiences. In all the verification variables, the averages remarkably increased at the end of the semester in comparison to the beginning; for listening, the average increased from 1.66 at the beginning to 4.16 at the end.

Table 9 shows the results of analyzing test differences in paired samples used at the beginning and the end of semester to evaluate communication skills based on Mentoring experiences. When the significance levels were analyzed, the absolute value of the t-value was from 6.221 ( $\mathrm{min}$.) up to 27.901 (max.), which exceeded 1.96 , for all the verification variables. The significance probability (both) was 0.000 . Thus, it is reasonable to consider that the research hypothesis is supported.

\section{4) Effects of Mentoring on improvement in Mentors' satis- faction with college life}

The mentors generally showed high satisfaction with Mentoring (4.58 to 4.92), probably because they were systematically educated and a variety of programs were provided to create rapport 
Table 10. Effects of Mentoring on satisfaction with college life (at the end of the semester)

\begin{tabular}{|c|c|c|c|c|c|c|c|c|}
\hline \multicolumn{9}{|c|}{ Statistics } \\
\hline & & $\begin{array}{c}\text { General } \\
\text { satisfaction }\end{array}$ & $\begin{array}{l}\text { Satisfaction with } \\
\text { methods used }\end{array}$ & $\begin{array}{l}\text { Satisfaction with } \\
\text { mentor roles }\end{array}$ & $\begin{array}{c}\text { Active } \\
\text { participation }\end{array}$ & $\begin{array}{l}\text { Satisfaction during } \\
\text { Mentoring }\end{array}$ & $\begin{array}{l}\text { Willing to } \\
\text { invite others }\end{array}$ & $\begin{array}{l}\text { Improvement in } \\
\text { adaptation of mentees }\end{array}$ \\
\hline \multirow[t]{2}{*}{$\mathrm{N}$} & Valid & 12 & 12 & 12 & 12 & 12 & 12 & 12 \\
\hline & Missing & 0 & 0 & 0 & 0 & 0 & 0 & 0 \\
\hline \multicolumn{2}{|c|}{ Average } & 4.83 & 4.92 & 4.92 & 4.92 & 4.58 & 4.92 & 4.83 \\
\hline \multicolumn{2}{|c|}{ Standard deviation } & 0.389 & 0.289 & 0.289 & 0.289 & 0.515 & 0.289 & 0.389 \\
\hline \multicolumn{2}{|c|}{ Variation } & 0.152 & 0.083 & 0.083 & 0.083 & 0.265 & 0.083 & 0.152 \\
\hline \multicolumn{2}{|c|}{ Sum } & 58 & 59 & 59 & 59 & 55 & 59 & 58 \\
\hline
\end{tabular}

between mentors and mentees. The various programs referred to here refer to the peer mentoring training courses conducted by the Suncheon Jeil College Student Counseling Center, including weekly PSP classes in Table 3. The peer mentoring training course consists of the basic attitude of conversation, helpful conversation, knowing the type of learning personality, and knowing the learning type of mentee.

The average shown in Table 10 is obtained by the satisfaction of mentoring activities to 12 mentors.

\section{DISCUSSION}

This study aimed to i) design a teaching and learning model of PSP class to which AL, PBL, and Mentoring were applied, and ii) implement the model to verify the effects of AL on team learning and identify improvements in problem solving ability through PBL and communication skills through Mentoring by conducting quantitative tests.

The statistical significance of the research results are as follows.

First, based on the significance of the research hypothesis, $\mathrm{AL}$ was proven to have effects of positively changing students' team learning satisfaction. When the significance level was analyzed, the absolute value of the $t$-value exceeded 1.96 in all the verification variables. The average satisfaction considerably increased from 2.548 ( $\mathrm{min}$.) at the beginning to 3.387 (max.) at the end of the semester.

Second, based on the significance of the research hypothesis, PBL was verified to have effects of positively changing learners' problem solving ability. When the significance level was analyzed, the absolute value of the $\mathrm{t}$-value was from 26.934 ( $\mathrm{min}$.) to 36.379 (max.), which exceeded 1.96, and the significance probability (both) was 0.000 . As for orientation of problems, the average considerably increased from 1.66 at the beginning to 4.69 at the end of the semester.

Third, based on the significance of the research hypothesis, Mentoring was verified to have effects of positively changing learners' communication skills. When the significance level was analyzed, the absolute value of the $\mathrm{t}$-value was from 6.221 ( $\mathrm{min}$.) to 27.901 (max.), which exceeded 1.96, and the significance probability (both) was 0.000 . As for listening, the average increased from 1.66 at the beginning to 4.16 at the end of the semester.

Fourth, Mentoring had effects of increasing Mentors' satisfactions with college life. The general satisfaction of the Mentors' with Mentoring activities was high, from 4.58 (min.) to 4.92 (max.).

\section{Academic and practical implications}

First, this study designed a teaching and learning model to which AL, PBL, and Mentoring were applied. Having implemented the model, analysis was undertaken of the effects of $\mathrm{AL}$ on team learning, of PBL on improving problem solving ability, of Mentoring on improving communication skills, and satisfaction of Mentors' with Mentoring activities.

Second, this study conducted a paired sample t-test to analyze the effects of $\mathrm{AL}, \mathrm{PBL}$, and Mentoring to prove their significance.

\section{Acknowledgements}

This paper was supported by funding from the Halla Newcastle PBL Education and Research Center. The author acknowledges the editorial support provided by Professor Margaret McMillan.

\section{REFERENCES}

Albanese, M. A., Mitchell, S. (1993). Problem-based Learning: A review of literature on its outcomes and implementation issues. Academic Medicine, 68, 52.

Barrows, H. S., Tamblyn, R. M. (1980). Problem-Based Learning: An Approach to Medical Education. New York: Springer Publishing Company. 
Carkhuff, R. R. (1972). The art ofhelping. Amherst. MA. HRD Pres.

Cho, Y. S. (2006). Theory and Practice of Problem-Based Learning. Seoul: Hakjisa.

Feldhusen, J. F., \& Treffinger, D. J. (1985). Creative thinking and problem solving in gifted education Kendall/Hunt Publishing Company.

Fink, L. D. (2004). Beyond small groups: harnessing the extraordinary power of learning teams In. L. K. Michaelsen, A.B. Knight and L. D. Fink (Eds.), Team-Based Learning: A transformative use of small groups. Westport, CT: Praeger Publisher, 3-26.

Gallagher, S. A., Stepien, W. J., Sher, B. T., \& Workman, D. (1995). A Model of Action Learning Program Design in Higher Education. Implementing problem-based learning in science classrooms, 95(3), 136-146.

Guilford, J. P. (1967). The nature of human intelligence. New York. McGraw-Hill.

Ha, C. Y., \& Lee, S. Y. (2014). The effect of the team-based learning model on critical thinking and self-directed learning in elementary science class. East-West Nursing Research Journal, 20(2), 154-159.

Jang, K. W. (2011). A Model of Action Learning Program Design in Higher Education. Educational Engineering Research, 27(3), 475-505.

Kahney, H. (1986). Problem solving: A cognitive approach. UK. Open University Press.

Kim, H. J., \& Um, Y. W. (2014). A Case Study on Action Learning Program for Faculty Development. Educational Engineering Research, 30(4), 839-878.30

Kang, I. A. (1999). Another teaching-learning model of constructivism: Focused on PBL Cho, Y. G. and others (co-author) constructivist pedagogy. Education Science History.

Kang, I. A., \& Joo, H. J. (2009). Re-conceptualization of the Learner-Centered Education: The Status Quo of the In-Service Teachers Learner-oriented subject education society.

Kim, J. E. (2008). The effect of college student mentoring skills on college life adjustment and satisfaction: Focusing on the comparison of differences according to the trust in mentor of Catering major students. Catering Management Research, 11(2), 77 101.

Kim, J. H. (2010). Effects of Relation Characteristics of College Student Protege with Mentor on Mentoring Function Department of International Office Administration. The Graduate School of Ewha Womans University.

Kim, S. G. (2010). Development and Application on Problem-Based Learning Model for Early Childhood Science Education of Preservice Teacher Department of Early Childhood E ducation, Graduate School of Paichai University Daejeon.

Kim, Y. K., \& Kim, N. R. (2015). Design and Implementation of Team-Based Learning of 'Pharmacology'. Learner-Centered . Curriculum Education Research. 15(4), 309-334. 15

Kim, Y. S. (2013). Design and Effectiveness of the Face-to-Face Instruction Applying Merrill's First Principles of Instruction Andong University Graduate School Doctoral Dissertation.

Lee, G. S. (2019). The effect of college students' communication skill on college adjustment and career preparation behavior Paichai University Graduate School of Education Master's Thesis.

Lee, K. H., \& Son, N. R. (2012). The Effects of Team-Based Learning on Early Childhood Play Guidance: Focusing on Learning Attitude, Learning Motivation, and Academic Self-Efficacy. Thinking development, 8(2), 151-170.

Lee, S. A. (2018). Development of Learner Evaluation Tool for an Action Learning Based University Class Department of Education Graduate School, Keimyung University.

Lee, S. J., Jang, Y. K., Lee, H. N., \& Park, K. Y. (2003). Research and development of life skills measurement tools-communication skills, problem solving skills. Focused on self-directed learning ability Korea Educational Development Institute.

Marquardt, M. J. (1999). Action learning in action. Mountain View Mountain View. CA: Davies-Black Publishing.

Michaelsen, L. K., Knight, L., Fink, D. (2009). Team-based Learning: A Transformative Use of Small Groups in College Teaching. VA: Stylus Publishing.

Mumford, M. D., Mobley, M. I., Reiter-Palmon, R., Uhlman, C. E., \& Doares, L. M. (1991). Process analytic models of creative capacities. Creativity Research Journal, 4(2), 91-122.

Park, S. B.(2017). The Influence of Medical Students' Self-Directed Learning Ability on Problem-Solving and Self-Efficacy in Clinical Performance. Department of Lifelong Education \& HRD, Soongsil University Graduate School of Education.

Park, S. M. (2006). Development and validation of mentoring function measurement tools for college students. Fisheries and Ocean Education Research, 18(1), 49-57. 18

Revans, R. W. (1982). The origin and growth of action learning. London. Chartwell-Bratt.

Ryu, D. Y. (2014). The structural relationship among elementary school teacher's communication competence, school organization culture, teacher efficacy, and subjective happines Soongsil University.

Shin, M. J. (2014). The relationships between communication ability, self-identity and college adjustment among college students Sahmyook University.

Shin, S. Y. (2019). An analysis of difference in team-based learning composed based on DISC behavior patterns on learning atti- 
tude, team task performance and learning satisfaction of job strategy class. Graduate School of Education consulting, Pukyoung National University.

Spitzberg, B. H. (1987). The relationship of interpersonal competence and skills to reported loneliness across time. Journal of So-

\section{cial Behavior and Personality, 2(2), 157.2}

Yoo, C. S. (2008). The Effects of a Communication Training Program on Interpersonal Relations and Self-esteem of Vocational College Students Master's thesis. Chonnam National University Graduate School Dissertation. 